\title{
TOWARD EFFECTIVE LEGAL REGULATIONS AND AN ENABLING ENVIRONMENT FOR INALIENABLE MUSLIM ENDOWMENTS $(A W Q \bar{A} F)$
}

\author{
Mohammed Hisham Dafterdar
}

\begin{abstract}
The accumulation of awqāf assets has created tremendous wealth for the welfare of the global Muslim community. However, due to a variety of historical reasons and the lack of an effective and enabling legal environment the role of the waqf as a useful tool for socio-economic development has generally been neglected and often forgotten. Awqāf as a faith-based charitable institution has generated interest beyond philanthropists and shari 'ah scholars and is no longer seen as exclusively religious. The sector is in fact an industry and is being subjected to increased scrutiny by governments and regulatory authorities. This article investigates the possible model character for corporate governance as well as sustainability and profitability issues pertaining to awqāf.
\end{abstract}

\section{Introduction}

The importance of the $a w q \bar{a} f$ sector is seen in terms of the huge assets it controls, in its social expenditure, in the number of people it employs, and in its significant contribution to the economy which accounts for as much as 10 per cent of the GDP of some countries. ${ }^{1}$ With such a significant economic output, and growth in the number, size and diversity of organisations entrusted with awqäf properties for social programmes, $a w q \bar{a} f$ as a faith-based charitable institution has generated interest beyond philanthropists and sharī 'ah scholars, and the sector is no longer seen as exclusively religious. With a broader business focus, it became clear that the sector is in fact an industry and is being subjected to increased scrutiny by governments and regulatory authorities.

The size of the sector and its growing economic importance qualify it for serious attention by legislators and standards setters of the Islamic financial industry. In order to rejuvenate the institution of waqf and reverse the trend of neglect and to enhance its role in social and economic development, a number of issues must be addressed: How should the regulatory framework operate? Would the regulation help

\footnotetext{
* Mohammed Hisham Dafterdar is a senior advisor at Unicorn Investment Bank, Manama, Bahrain.
} 
or hinder the development of $a w q \bar{a} f$ and the creation of new waqfs? Is uniformity needed? And how will this help? What is an ideal model for corporate governance? Is that model workable within the parameters imposed by other features of the business and political environment? What about sustainability and profitability and shouldn't awqā f be profitable in order to be sustainable? Do we see a conflict between $a w q \bar{a} f$ as a not-for-profit sector and the pursuit of growth and profitability? In the following, we shall focus on these and other issues that are relevant for the integration of $a w q \bar{a} f$ into the mainstream of the Islamic financial industry. We will also address matters which are of concern to regulatory authorities, awq $\bar{a} f$ organisations and to all $a w q \bar{a} f$ stakeholders.

\section{The 'Third Sector'}

The institution of waqf is a Sunnah established by the Prophet which became the base upon which the Islamic socio-economic development model was built. Historically, the practice of $a w q \bar{a} f$ evolved to become the main provider of many services that the modern welfare state today strives to offer. As a feature of the Islamic civilisation, the history of $a w q \bar{a} f$ is rich with impressive achievements in the field of social services ranging from education to healthcare and to non-medical welfare. $A w q \bar{a} f$ served the poor in particular and society in general. Awq $\bar{a} f$ also contributed to the protection of the environment and the preservation of the flora and fauna. Mosques and shrines, major hospitals and universities, libraries and museums, animal shelters and bird sanctuaries were established as waqf. However, despite these achievements, the history of $a w q \bar{a} f$ is rife with turbulent events. For centuries, governments considered $a w q \bar{a} f$ as public property and part of the national wealth and exercised different degrees of control over this institution. The control by governments had several negative impacts on the waqf system and led not only to much less new awqā $f$ being donated, but also to the expropriation of large areas of $a w q \bar{a} f$ land. ${ }^{2}$ In addition, the corrupt and unscrupulous behaviour of some waqf managers (mutawallīs/nāzir) has led to the loss and deterioration of properties so that many remained un- or underdeveloped, while the latent wealth of $a w q \bar{a} f$ continues to be largely untapped.

One of the major impediments to growth is the lack of proper legal environment. Legislative reforms are required in Muslim countries and in countries with sizeable Muslim populations, in order to eliminate discrepancies between the various waqf laws and remove obstacles that hinder the development of $a w q \bar{a} f$ as a viable socio-economic sector.

Awqāf (sing.: waqf) is an Arabic word meaning assets that are donated, bequeathed, or purchased for the purpose of being held in perpetual trust as ongoing charity (sadaqah järiyah), or for a general or specific cause that Islam regards as socially 
beneficial. ${ }^{3}$ This condition of perpetuity has led over the years to a considerable accumulation of societal wealth that plays an important role in improving the lot of the Muslim community. As a reflection of its increasing contribution to the economy, $a w q \bar{a} f$ has come to be known as the third sector, as distinct from the government sector (central, state and local government) also known as the first sector, and the private sector (business and corporate sector) sometimes called the second sector. ${ }^{4}$

$A w q \bar{a} f$ organisations are Islamic not-for-profit entities that represent a vast array of social, cultural and economic activities. They are not part of government although many perform a public service. Their operations dovetail into all sectors of the economy and include a wide range of industries including but not limited to real estate, education, healthcare, social services and recreation. Being an awqāf organisation does not necessarily mean being small. A considerable number of them are large-scale organisations operating in different countries, controlling substantial assets, and employing significant numbers of people.

\section{The Legal Status and Ownership of Awqāf}

The concept of ownership in $a w q \bar{a} f$ can be quite complex and somewhat confused. There are differences among the four schools of Sunni jurisprudence (madhāhib) on who owns the waqf assets: The Shāfi îs argue that ownership of awqāf belongs to God and what appears to be human ownership is in fact a matter of trusteeship. The Ḥanafĩs and Ḥanbalīs view that the waqf belongs to the beneficiaries although their ownership is not complete in the sense that they 'own' only the benefit or usufruct of the property but cannot dispose of it or use it in any way different from what was decreed by the wāqif (founder of the waqf). Mālikī jurists are of the view that a waqf remains in the ownership of the wäqif and is inherited by his/her legal heirs. ${ }^{5}$ Thus the Mālikīs do not insist on the perpetuity of the waqf like the Shāf 'īs, Ḥanafīs, and Ḥanbalīs. Ibn 'Arafah, a Mālikī scholar, defines perpetuity "as long as the property lasts" to include such perishable assets as livestock, trees, items of furniture and mobile assets. ${ }^{6}$ The dispute among jurists on the principle of perpetuity versus temporality of the waqf is mainly a matter of ijtihād (legal reasoning) and is incidental to the noble objective of birr (donating for a benevolent purpose). There are, however, mechanisms by which perishable and short-lived $a w q \bar{a} f$ assets can be held in perpetuity. For example, non-human or biological assets such as farm animals, crops and orchards are self-generating and regenerating assets. On the other hand, there are methods by which inanimate assets can refinance themselves and therefore can be renewed or replaced by proper provisioning. According to Shaykh al-Zarqā', "everything in waqf is subject to ijtihād and there is no single ruling in it that gained unanimity except that the waqf purpose must be benevolent (birr)".? 
The fact that a waqf outlives the wäqif, the mutawalli and the beneficiary, means it has a separate and independent personality (thimmah) of its own. This is akin to the concept of the continuing legal entity which was developed in the West over the last three centuries. The waqf, however, differs from the corporate entity by virtue of three qualifying conditions: perpetuity, irrevocability and inalienability. While a corporate entity can dispose of its assets and can imminently be terminated by its shareholders, the perpetuity of $a w q \bar{a} f$ is protected by a series of sharī $a h$ rulings which relate to non-disposal of $a w q \bar{a} f$ assets through sale or transfer. The awqāf is conceived as a sacred trust which means that even if the original purpose of the waqf ceases to exist, the benefit can be assigned to another charitable purpose and the property remains in the domain of the waqf.

The Ja'farī legal school of Twelver Shi'ite Islam, which comprises the overwhelming majority of Shi 'ites today, has similar views as the Shāfi' īs in respect of the ownership of $a w q \bar{a} f$, upholding the general rule of 'alienating the asset and expending the usufruct'. However, the Ja 'farīs apply 'aql (intellect) instead of qiyās (deductive analogy) in the Sunni schools, which gives Twelver Shi ite jurists more flexibility when establishing Islamic laws. ${ }^{8}$

\section{Family Awqāf}

Some of the earliest $a w q \bar{a} f$ were founded for the benefit of the poor members of the family. ${ }^{9}$ Later on, family $a w q \bar{a} f$ (waqf $a h l \bar{\imath}$ ) were established for mundane reasons such as to protect a property from falling into the wrong hands or to reduce its exposure to risks such as confiscation by the state or claim by creditors. ${ }^{10}$ As a waqf, the property is inalienable and therefore cannot be sold or pledged as collateral. From a legal point of view, the beneficiaries of the family waqf are family members who are regarded as 'objects' having only a 'contingent' interest in relation to the waqf property.

Many family $a w q \bar{a} f$ were created as testamentary trusts, arising upon the death of the founder. Some of these family awqāf were designed to circumvent Islamic inheritance rules, favouring the sons and depriving the daughters or disentitling them upon marriage. ${ }^{11}$ These testaments had a particularly negative impact on the family unity and cast a shadow over the waqf's utility as a family wealth management tool, as they gave rise to disputes that brought them under heavy attack in several Muslim countries. Some countries enacted laws that dissolved existing family $a w q \bar{a} f$ and prevented establishing new ones as happened in Egypt, Syria and Lebanon where family $a w q \bar{a} f$ properties were quarantined as inherited assets and then liquidated and/or distributed to the beneficiaries according to shari 'ah inheritance rules or the intestacy laws of the country. ${ }^{12}$ 
The dissolution of family awqa $\bar{f}$ in some countries is attributed to many factors including the exponential increase in the number of beneficiaries after a few generations to the point where the benefit accruing to an individual is insignificant; breakdown of the relationships among family members; disputes arising between the beneficiaries and the mutawallīs; and the conflicts of interest arising from mutawallīs who are also beneficiaries of the waqf they control, and consider their role as a right that can be passed on to heirs as part of their estate.

\section{Regulating Awqāf: A Historical Perspective}

Throughout Islamic history, governments considered $a w q \bar{a} f$ as a national resource and tried to bring it under state control. The first attempt by the state to control awqāf took place in Egypt during the period of Mamluk rulers (1250-1517). This was so strongly objected to by Muslim scholars that it was quickly withdrawn. The change came with the Ottomans (1453-1922) who in the early nineteenth century established a special ministry to oversee $a w q \bar{a} f$ affairs and enacted laws for awqāf. The most important of these laws was the waqf law of 1863 which regulated the registration, control and management of waqf properties. This law came as a sweeping reform to the prevailing chaos and rogue behaviour of some mutawallīs in the management of awq $\bar{a}$.

During the first half of the twentieth century many Muslim countries issued awq $\bar{a} f$ laws that were based on the Ottoman laws; and by the second half of the twentieth century, most Arab and Muslim countries had gained their independence and enacted new laws that put $a w q \bar{a} f$ under government control. ${ }^{13}$ They established ministries and directorates under the central government to manage $a w q \bar{a} f$ as a public sector instrumentality. However, the degree of control varied from one country to another. ${ }^{14}$

In Egypt, awqā $f$ land accounted for one quarter of the agricultural area of the country when Muhammad 'Alī Pasha (r. 1805-48) brought them under state control. ${ }^{15}$ The state's control of awqāfland continued until Nasser in 1952 nationalised them as part of the policy of land reform. Large areas of $a w q \bar{a} f$ land were also nationalised in Algeria, Syria, Tunisia, Turkey and Palestine. The nationalisation of $a w q \bar{a} f$ land and the transfer of responsibility from private mutawallīs to ministries of awqa $\bar{f}$ meant the demise of the independent identity of the waqf institution and endorsed the $a w q \bar{a} f$ as an instrument of government policy. ${ }^{16}$

The government's control of $a w q \bar{a} f$ has led to significant decline of the sector, such that the $a w q \bar{a} f$ 's role as a welfare mechanism was reduced to the point that it became a burden on the public purse. In recent years, many Muslim countries embarked on reforming the administration of $a w q \bar{a} f$ by separating the custody function from $a w q \bar{a} f$ asset management by establishing separate entities to develop and manage $a w q \bar{a} f$ properties. They recognised that the $a w q \bar{a} f$ has a separate 
personality (thimmah) and that $a w q \bar{a} f$ funds are not to be commingled with public funds. Egypt in 1971 established the Egyptian Awqaf Authority to take over the management of awqā f properties from the Ministry of Awqaf. In Sudan, the Federal Corporation of Awqaf was established in 1987. Kuwait, in 1993, founded the Awqaf Public Foundation. In Jordan, the Ministry of Awqaf, Islamic Affairs and Holy Places established the Awqaf Properties Investment Corporation. In Malaysia, at the federal level, the Prime Minister's Department, in March 2004, established the Department for Awqaf, Zakat and Hajj (JAWHAR) to coordinate the activities of the state's religious councils in matters relating to awqā $f$ development. The latest is the establishment of Qatar Awqaf Authority in 2007 to take over the activities of the former Awqaf Department at the Ministry of Awqaf and Islamic Affairs.

In Iran, the Waqf and Charity Organisation (WCO) was established in 1984 as the official body under the Ministry of Culture and Islamic Guidance to oversee, promote, manage and carry out activities and projects that are founded as awqā f. The investment and operating arm of WCO is Iran's Endowment Fund (IEF), whose objectives are to develop, revive, expand, reconstruct and rehabilitate $a w q \bar{a} f$ properties, and provide social assistance as directed by the Waqf and Charity Organisation. ${ }^{17}$

In non-Muslim countries, Muslim communities administer their $a w q \bar{a} f$ properties in accordance with the trust and foundations laws of the country. Many of these laws were inspired from the Islamic waqf system. Muslim communities in these countries establish non-profit organisations that hold titles to waqf properties.

\section{Custody and Management of Awqāf}

In principle, the waqqif through a deed determines the objectives of the waqf and its management and succession processes. The waqf manager or trustee (mutawallī) näzir) holds the title of the waqf property, exercises legal control and is bound by fiduciary responsibility and moral obligation to protect and administer the waqf for the benefit of the beneficiaries in accordance with the terms of the waqf deed. Mutawallīs are expected to comply with both the letter and spirit of the waqf condition. The importance of the conditions of the wäqif is indicated by the often quoted maxim: "The conditions of the wāqif have the same legal force as the edicts of the legislator." However, some flexibility is afforded through the differences of the schools of jurisprudence. The early jurist Abū Hanifah, for example, allows changing the conditions of the wāqif if there is an overriding public benefit (mașlahah 'ammah), or when the beneficiaries or the purpose of the waqf comes to an end. ${ }^{18}$

The authority of mutawallīs to act and make decisions on behalf of the waqf carries an immense responsibility and their duties are wider and more onerous than they were assumed to be. As trustees, mutawallīs have the primary responsibility for 
prudent management of assets in their custody. As such, mutawallis are expected to have a certain level of business skills and investment knowledge to support their role in monitoring the safety and performance of assets under their control. However, because of the nature of $a w q \bar{a} f$, its religious message and social application, it seems logical that those who are entrusted with the custody and management of awqāf properties are more religiously conscious and therefore employ their faith when managing. But the operating environment is rapidly changing and as a result the role of the mutawallīs is also changing. Mutawallīs are not only required to act in good faith for the best outcomes for the waqf, but also to be seen acting diligently and in a principled manner to build trust among those they deal with. They need to develop competence and behavioural characteristics in order to change the traditional image of the mutawallīs as persons who can be a business risk being concerned only with the social aspects of the waqf. Mutawallis have the responsibility to safeguard and grow assets in their custody and produce returns rendering it harder to act solely on their beliefs.

\section{Enabling a Legal Environment}

One of the major impediments for the development and growth of $a w q \bar{a} f$ is the lack of a constructive legal and regulatory environment. $A w q \bar{a} f$ is a voluntary sector built on voluntary contribution of assets and on mostly voluntary contribution of services. Therefore, the regulatory environment should foster public confidence in the waqf, encourage donors and volunteers, and promote ethical and proactive behaviour of the mutawallīs. Donors usually are generous and feel more comfortable with organisations whose operations are governed by clear and applicable standards of accountability and transparency. Also, financiers are more willing to provide capital for projects of organisations that adopt best practices of corporate governance. ${ }^{19}$

Unlike commercial organisations, the services delivered by awqā $f$ may often be intangible and difficult to measure. Commercial organisations have clear delineations about shareholders, with all reporting geared towards profits. The position is not so simple for $a w q \bar{a} f$ organisations. Regulated mainly by the shari ' $a h$ and restricted by wāqif conditions, many awqā $f$ organisations consider regulatory and compliance issues of corporate governance as costly and unnecessary administrative burdens. Unlike commercial organisations, staff in an awqāf organisation is comprised of low-paid professionals or volunteers who have chosen to work in awqāf for less tangible rewards. Their loyalty is more to the cause of the waqf than to its organisational entity. They are mainly concerned with the social aspects and pay little attention to financial efficiency or accountability. They claim that by legislating what is effectively an issue of faith, the very fabric of $a w q \bar{a} f$ will be undermined. 
Strategy formulation in an $a w q \bar{a} f$ organisation can be subject to a unique and complex set of influences. What is deemed to be appropriate strategy will be conditioned by the concern not to violate the conditions of the wāqif, the wishes of the donors, and the legal environment. The concerns of non-beneficiary stakeholders should also form part of awqā organisations' responsibilities and as such mutawallīs should have the duty to act in the interest of the entire community. These days no organisation is immune to public scrutiny, not even a shelter or an orphanage that does not have a blemish to its name. Therefore the impact of the awqä 's performance on the community must be positive and the organisation must be seen to be operating in compliance with community standards and expectations.

The major challenge faced by $a w q \bar{a} f$ is ensuring that the huge treasure of $a w q \bar{a} f$ is preserved, developed, and continues to grow and contribute to the social and economic development of the ummah. This can be met only by creating an enabling legal environment - one that creates a level playing field for $a w q \bar{a} f$ managers and mutawallis and causes them to be transparent and accountable and enables them to strengthen their operations in order to fulfil their obligations to donors, beneficiaries and all other stakeholders.

\section{Flexible and Efficient Awqāf Laws}

$A w q \bar{a} f$ is a global sector and many awqāf organisations have an international presence acting as trustees and custodians (mutawallīs) of a plethora of assets, cash flows and cross-border investments. It is not unusual to find the waqf property in one country and the beneficiaries in another while the waqf organisation is based in a third country. ${ }^{20}$ Thus, a waqf may fall under different jurisdictions depending upon the type of connection to the jurisdiction: the connection of the waqf asset to the jurisdiction, the connection of the awqa $f$ organisation (or trustee) to the jurisdiction, and the connection of the beneficiaries to the jurisdiction. Accordingly, the same waqf may be subject to different laws depending upon the type and degree of connection to the jurisdiction. What is needed is a unified awqa $\bar{f}$ law that applies across countries.

$A w q \bar{a} f$ are regulated by the country's local $a w q \bar{a} f$ law, if there is one, or are subject to laws which are designed for other sectors. In general, the existing $a w q \bar{a}$ flaws are not written to operational requirements. They mainly define the rules of overseeing the waqf and the relationships among stakeholders, but fall short of addressing the developmental needs of the sector. On the other hand, regulating awqāf by applying other laws puts the sector at a disadvantage inasmuch as the sector's specific requirements would not be considered by such laws. The harmonisation of $a w q \bar{a} f$ laws across national boundaries is essential for the development and growth of the sector. However, there is no unanimous agreement on developing 
awqā flaws with global application. Some jurisdictions consider that their existing laws are adequate for regulating their $a w q \bar{a} f$. To be acceptable internationally, the global awqā law should provide only the conceptual framework and it should be broadly stated to allow individual governments to modify it taking into account the legal code, the social structure, the ethnic composition and the particular needs and circumstances of the country.

The ideal $a w q \bar{a} f$ law should be a principle-based framework that provides an authoritative benchmark for $a w q \bar{a} f$ organisations across jurisdictions. The intention is not to substitute a local law by another or to morph all the different national $a w q \bar{a} f$ laws into one global law. A model international $a w q \bar{a} f$ law should give a strong but flexible legislative framework to facilitate its worldwide use. If it is too strict or too detailed, then it will be met with less satisfaction and more resistance. It should be designed to eliminate any impediments, stimulate $a w q \bar{a} f$ development and initiatives, and protect $a w q \bar{a} f$ properties in the country. Like the "corporations act' in common law countries, the $a w q \bar{a} f$ law should have a system of replaceable rules, so that $a w q \bar{a} f$ organisations can design their by-laws to fit their needs and circumstances more closely. From a juridical point of view, the awqa $f$ law should be interpreted less strictly than other laws and more attention should be given to the intent of the law than its formal expression.

The sector shows great concern for ethics based on fundamental values such as honesty, integrity, fairness, trust and commitment. These values are especially important for $a w q \bar{a} f$ as it is through this sector where social impacts are more visible. While standard regulations play an important role in protecting all stakeholders, in these areas $a w q \bar{a} f$ organisations are better placed to regulate their own activities, and can produce more social cooperation and better economic outcomes than any government-mandated rules.

\section{Corporate Governance}

A key issue to $a w q \bar{a} f$ is the need for transparency and assurance of the way assets and resources are managed in the interests not only of the beneficiary groups but of all stakeholders. The lack of uniformity in reporting and the failure of many awqa $\bar{f}$ organisations to produce financial reports, does limit their accountability to the $w \bar{a} q i f \mathrm{~s}$, to beneficiaries, and other stakeholders. Most $a w q \bar{a} f$ organisations use their annual reports as public relations tools that are designed to present themselves to potential donors and supporters as an attractive entity for donors' funds. This type of reporting is largely unregulated leading to problems of comparability and reliability. Confusion, uncertainty and sometimes unscrupulousness are perceived in the texture of $a w q \bar{a} f$ organisations. Therefore, in order to correct this image and to bridge 
$a w q \bar{a} f$ culture of philanthropy and issues of organisational management, a suite of internationally recognised standards of corporate governance must be established.

The establishment of sector-specific standards requires time to evolve, and for $a w q \bar{a} f$ the setting of standards faces higher hurdles. Based on fundamental social values, awqāf governance standards should consider the legal, ethical and human issues and deal with how awqa $f$ organisations should act to be transparent and accountable in their programme operations, asset and resource management, fund raising, financial management, and non-financial performance. To be effective, these standards should be given the force of law, such that breaching the standards is a breach of the law.

Contrary to popular belief, awqāf organisations have many similarities to private sector corporations. In some ways, it seems like there is very little difference to the corporate world - assets need to be managed, revenues to be earned, bills to be paid and reports to be made. They also undertake a wide range of activities such as project management, raising of finance, and maintenance of key banking relationships. Therefore, awqa $\bar{f}$ may adopt some of the private sector's concepts of corporate governance and apply some of its commercial principles and benchmarks.

Corporate governance standards may initially be introduced as a 'good practice guide' for awqā $f$. The 'Guide' can be designed as a working tool for mutawallīs to improve accountability, transparency and waqf management. It might include provisions covering qualifications, appointment and responsibilities of awqa $\bar{f}$ mutawallīs, such as administering waqf deeds and the conditions of the wāqif, remuneration and management fees and procedures to be followed for allocating contributions and procedures that help ensure that $a w q \bar{a} f$ assets are invested with due care, skill and diligence.

The perpetuity of the waqf creates issues of trusteeship (wilāyah) succession and highlights the need for the corporate mutawallī. While a waqf can be managed by an individual, a corporate structure has obvious advantages. An incorporated entity has indefinite life, a board of directors, and allows the segregation of duties and distribution of responsibilities according to areas of specialisation. A corporate structure underlines the need for licensing regulations where mutawallīs or waqf administrators need to be certified and licensed. The certification of mutawallīs sets a process that will see standards of appropriate qualification and personal competence to ensure that awqäf mutawallīs possess the highest level of transparency, accountability and professionalism. Just as company law provides that public companies appoint an auditor, awqā f governance laws should also make it mandatory for mutawallīs and administrators to be audited. A perceived conflict between the mutawall $\bar{l}$ and his obligations to the waqf or non-compliance with the regulations could lead to revoking of the mutawallìs licence. ${ }^{21}$ 


\section{Issues of Sustainability and Profitability of Awqāf}

$A w q \bar{a} f$ organisations, like all organisations, have to generate revenues to fund their operations. They need to generate sufficient cash from the assets in custody, or appeal to donors who may have their own particular view of what objectives and services the organisation should be providing. However, donations are uncertain and unpredictable and as a result of the lingering financial crisis and the mounting pressure on charities to declare their funding sources, corporations and individuals are now giving less. Many awqā $f$ organisations have reported that there has been a noticeable reduction in donor funds. Thus, awqā $f$ organisations are finding it necessary to expand their revenue base to include steadier forms of income from commercial activity and investments. Their orientation towards social services is getting more intimately enmeshed with the pursuit of business interests. This spills over into the increasingly competitive environment where $a w q \bar{a} f$ have to compete in the marketplace with the commercial sector, and raises concerns about the impact of such activities on the social mission of awqāf.

Awq $\bar{a} f$ organisations have different purposes and processes for generating revenues. Profitability is not their only credo. Their obligation for asset custody and perpetuity emphasises ongoing viability rather than pursing short-term profit maximisation. Stakeholders include donors, wāqifs, mutawallīs, beneficiaries, clients, employees, volunteers and government. Each of these groups consists of individuals of diverse nationality, culture, age, education and socio-economic status. Such groups will have different values, interests, goals and perceptions of acceptable performance.

In responding to this list of stakeholders, awqa $\mathrm{a}$ organisations may face a problem of balancing financing and operational objectives. The financial objectives can be readily expressed in quantitative terms, while operational objectives are more conventionally expressed in qualitative terms. There is the risk of overemphasising the financial objectives at the expense of the operational objectives, thereby inducing a form of role-reversal where operational objectives support financial objectives, rather than the financial objectives support the organisation's operational objectives. Thus $a w q \bar{a} f$ organisations must seek a balance between being financially efficient and socially effective. There is little use in being a highly cost efficient operation if the organisation is proving to be ineffective in delivering successful outcomes in operational terms. Likewise, an awqāf organisation that is highly effective in meeting its operational objectives, but which is inefficient financially, soon finds itself unable to continue delivering its services as resources drain to critical levels.

The dichotomy between sustainability and profitability is false. There is a misconception among some that because an organisation is a waqf, it should not seek profits. Some stakeholders believe that $a w q \bar{a} f$ organisations should break even or 
distribute the surplus if there is one. Responsible $a w q \bar{a} f$ organisations, however, do try to have profitable operations to ensure their long-term sustainability and ability to realise their mission well into the future. Imagine, for example, an orphanage operated by a waqf organisation. If it does not have any surplus funds to meet ongoing operating and future capital costs, the orphanage may be forced to close down. The inability to access any surplus funds from its own reserves may result in the withdrawal of a much needed community service.

\section{Policy Implication}

With the rise of popular ideas like 'human rights' and 'economic equality', governments in Muslim countries assumed direct responsibility for the welfare of their citizens and the role of $a w q \bar{a} f$ was marginalised. However, the state has been unable to serve efficiently all of the welfare purposes, especially the delivery of speedy aid and humanitarian support to vulnerable groups. On the other hand, faith-based charity institutions such as waqf and zakāh enjoy a higher degree of popular trust having grassroots recognition and much better access to people in need of support than any government agency.

Given the apparent support for $a w q \bar{a} f$ at the local and national levels, the sector need not operate at the periphery of socio-economic activity, but should rather be mainstreamed within the state's legal, social and economic systems. The waqf has relations with all areas of social and economic development such as housing, employment, social amenities, investment and commercial activity at zero cost to the state. Therefore, a great deal of thought should go into government policies which impact on the $a w q \bar{a} f$ as it intersects with other sectors of the economy.

$A w q \bar{a} f$ is a business sector, albeit not-for-profit, and despite its role as a welfare mechanism, or perhaps because of it, the $a w q \bar{a} f$ sector appears to have an edge over other sectors. The sector has been regarded as relatively resilient and recession proof. Awqāf organisations are resistant to market forces because they control donated prime assets, have access to free funds and services, have low overheads and enjoy tax exemptions, can turn social projects into cash-flow projects, and exercise considerable discretion in their operations. Yet, because of $a w q \bar{a} f$ 's private and usually esoteric nature, and lack of certainty about how it is governed and regulated, the sector appears to work in isolation from other sectors.

$A w q \bar{a} f$ is now getting more attention from both the public and the private sectors. Awqā organisations are now competing commercially in a wide range of business activities such as real estate, healthcare, trade, industry and agriculture. As awqāf organisations are now entering into various types of partnerships with the private sector, disputes are likely to arise and frustrate such arrangements particularly in the areas of 'business versus charity'. 
Legal reforms concerning awqāf have loomed large in comparative studies of law and society. Enacting an $a w q \bar{a} f$ law will invariably involve striking a balance between protecting $a w q \bar{a} f$ assets, developing the sector, maintaining equitable relationships with other sectors and examining the effect of other laws on awqāf. In an economic, social and governance context, the law should assist in restoring faith in $a w q \bar{a} f$ and in creating a more efficient sector.

There are concerns about extending regulatory control across countries. Applying the same rules to control organisations under different jurisdictions is always a challenge from a regulatory point of view. One set of international standards for $a w q \bar{a} f$, such as the International Financial Reporting Standards (IFRS) for accounting or Basel II for banking, is for the most part a good thing, ultimately creating a more efficient sector. But it must be recognised that different circumstances and disparate cultures exist in different countries and that each country may have to do its own thing in terms of the form of its $a w q \bar{a} f$ standards. As the international standards gain acceptance, governments will be encouraged to use them directly as their national standards in regulating $a w q \bar{a} f$ organisations operating in and from their territories.

\section{Conclusions and Recommendations}

Awq $\bar{a} f$ institutions are effective organisations for the socio-economic, cultural and religious development of a country. They have no direct political involvement, although they exercise considerable influence on the country's political and social life. Governments now realise the $a w q \bar{a} f$ 's significant contribution to their economies and consider the development of this sector as a strategy to boost the economy and complement the government's social initiatives.

- One of the most critical problems facing the efforts to develop the awqāf sector is the widespread lack of regulations prescribing acceptable norms of corporate governance. As charitable institutions, awqāf organisations are perceived to lack the organisational discipline of for-profit corporations. This has resulted in a very slow pace of developing awqāf properties, hence the reason we see many awq $\bar{a} f$ properties often in prime locations remaining vacant, under-developed, or under-utilised. Some have even been lost due to squatting, encroachment or sheer neglect.

- The issue of corporate governance is central to the idea of 'sustainable development'. Awqā $f$ must be transparent and accountable in respect of their funding and operations. Today, awqāf organisations have a broad business focus. They are taking responsibility for a wider range of activities in the commercial, industrial, agricultural and services sectors. Areas where guidance is required include institutional, legal and regulatory disciplines. This involves 
gate keeping and stewardship of awqāf properties and the empowerment of mutawallīs and mangers of $a w q \bar{a} f$ properties to enable them to charter the continued growth of their organisations.

- The renewed interest in $a w q \bar{a} f$ offers an opportunity to learn from the mistakes of the past and to construct a modern legal and regulatory framework. There will be a lot of footwork in putting an international awqāf law into practice. There needs to be cooperation among regulators to develop a global awq $\bar{a} f$ law that rationalises legislation among jurisdictions.

- Islamic regulatory and standards setting bodies of the Islamic financing industry should embark on a comprehensive study of $a w q \bar{a} f$. The collaboration of institutions like the Islamic Fiqh Academy, Islamic Financial Services Board (IFSB) and Accounting and Auditing Organisation for Islamic Financial Institutions (AAOIFI), together with the Islamic Development Bank (IDB) and Islamic Research and Training Institute (IRTI) and other related parties, will make it possible for an international awqāf law to evolve in a responsive and uncontroversial manner. Recognising that $a w q \bar{a} f$ organisations are non-profit entities holding valuable assets and providing essential social services, the law should offer adequate protection for $a w q \bar{a} f$ assets and to mutawallīs and donors.

- The ultimate goal is to have succinct, relevant, understandable and implementable standards that optimise efficiency and effectiveness of the sector and the knowledge, expertise and leadership of awqāf professionals.

With the right transparency, stability, long-term planning and guidance, the prospects for $a w q \bar{a} f$ are great and the more we delay this important concept, the more the $a w q \bar{a} f$ sector is placed at a disadvantage progress-wise.

\section{Notes}

1. Fahim M. Khan, "Integrating Faith-based Institutions (Zakat and Awqaf) in Poverty Reduction Strategies", [Islamic Research and Training Institute (IRTI/IDB)], 2007, available online at http:// ctool.gdnet.org/conf_docs/Khan_paper_BRP_wk.doc (accessed on 10 March 2011), 14. See also the news release by Johns Hopkins University, "Nonprofit Contribution to GDP Enormous, New Study Reports", available online at http://www.jhu.edu/news/home07/sep07/gdp.html (accessed on 10 March 2011).

2. Murat Çizakça, "Awqaf in History and Its Implication for Modern Islamic Economies", Islamic Studies 6, no. 1 (November 1998), 2.

3. See Shaykh Muḥammad Abū Zahra's awqāf lectures, Muḥạ̄arāt fì 'l-waqf (Cairo: Dār al-Fikr al-'Arabī, 1971, 2nd ed.), 5.

4. Habib Ahmad, Legal Environment and Nonprofit Sector: Implications for Growth of Awqaf Institutions (Jeddah: Islamic Research and Training Institute, Islamic Development Bank, 2007), 3.

5. Aḥmad b. Muḥammad al-Dardīr, al-Sharh al-kabìr, with the commentary by Muhammad b. Aḥmad b. 'Arafah al-Dasūqī (Beirut: Dār al-Fikr, 2002) 4:79. 
6. Monzer Kahf, "Towards the Revival of Awqaf: A Few Fiqhi Issues to Reconsider", paper presented at the Harvard Forum on Islamic Finance and Economics, Harvard University, 1 October 1999, available online at http://monzer.kahf.com/papers/english/FIQHI_ISSUES_FOR_REVIVAL_OF_ waqf.pdf (accessed on 8 March 2011), 1-4.

7. Shaykh Muștafā Aḥmad al-Zarqā̄', Aḥkām al-waqf (Damascus: University of Damascus Press, 1947) [in Arabic], 10-15.

8. For some aspects of $a w q \bar{a} f$ in Shi 'ite Iran in the early modern period see Christoph Marcinkowski (ed.), "Custodians of Sacred Ground: The Mutavallis of Safavid Iran's Major Shi'a Shrines in the Administrative Handbook Dastur al-Muluk", Journal of Shi'a Islamic Studies 1, no. 2 (April 2008), 96-116.

9. The creation of family waqfs was encouraged by the Prophet in many hadiths. For examples of family waqfs by the Companions of the Prophet see Aḥmad b. 'Umar al-Khașșāf, Aḥkām al-awqāf (Cairo: Maktabat al-Thaqāah al-Dīniyyah, 1996), 8-17.

10. Murat Çizakça, "Awqaf in History and Its Implication for Modern Islamic Economies", Islamic Economic Studies 6, no. 1 (1998), 51.

11. Thomas van den Wynen, "Note on the Origin and Uses of Trust-Waqfs", Southwestern Law Journal 3 (1949), 165 n. 43.

12. Egyptian Law No. 180 September 1952 amending existing Law of Waqf Article 3; Syrian Legislative Decree No. 76 amended by Leg. Decree No. 97 of Nov. 26, 1949; Lebanese Law of Dhurri Waqf, March 1947, Article 13.

13. Awqā laws were enacted in Egypt and Jordan in 1946, Lebanon in 1947, Tunisia in 1956, Iraq in 1959, India in 1954, Malaysia in 1956, and Pakistan in 1979.

14. Jan-Erik Lane and Hamadi Redissi, Religion and Politics: Islam and Muslim Civilization (Farnham, Surrey [UK]: Ashgate, 2009, 2nd ed.), 101-2.

15. Monzer Kahf, "The Role of Waqf in improving the Ummah Welfare", paper presented at the International Seminar on Waqf as a Private Legal Body, organised by the Islamic University of North Sumatra, Medan, Indonesia, 6-7 January 2003, available online at http://monzer.kahf.com/ papers/english/ROLE_OF_WAQF_IN_THE_WELFARE_OF_THE_UMMAH.pdf (accessed on 8 March 2011), 8.

16. Ibid., 14 .

17. Amjad Kilani, "An Overview on Awqaf and the Waqf Laws in the Islamic Republic of Iran" [in Arabic], (Tehran: Waqf and Charity Organisation of Iran 1383 AH solar [2002/2003 CE]), 33-42.

18. Eissa Zaki, A Summary of Waqf Regulations (Kuwait: Kuwait Awqaf Public Foundation, Department of Studies and External Relations, 2006), also available online at http://www.awqaf.org/Books/ Translated/mojaz_ahkam_alwaqf.pdf (accessed on 8 March 2011), 7-9.

19. Kerry O'Halloran, “Creating an Enabling Environment for Private Philanthropy: The Role of Charity Law in Northern Ireland", International Journal of Not-for-Profit Law 1, no. 3 (March 1999).

20. Awqāf organisations with cross-border investments and beneficiaries include the World Assembly of Muslim Youth (WAMY), the OIC Solidarity Fund, the Islamic Daawa Organisation, the Sharjah Awqaf General Trust and the Kuwait Awqaf Public Foundation.

21. al-Dardīr, al-Sharh, 4:88. An awqäf mutawallī can be removed by a judge if he is disqualified for any of these reasons. 